\begin{tabular}{|c|c|c|}
\hline Beitr. Ent. & Berlin & ISSN 0005-805X \\
\hline $\mathbf{5 0}(2000) 1$ & S. $103-118$ & 11.04 .2000 \\
\hline
\end{tabular}

\title{
To the knowledge of the African subgenus Planeteros of the genus Melaneros
}

\section{(Coleoptera: Lycidae)}

With 29 figures

\section{SERGEI KASANTSEV}

\section{Summary}

Nine new species, Melaneros (Planeteros) crucifer n. sp., M. (P.) flos n. sp., M. (P.) drymophilus n. sp., $M$. (P.) terrier n. sp., $M$. (P.) petrovi n. sp., $M$. (P.) helicofer n. sp., $M$. (P.) helicophilus n. sp., $M$. (P.) arndti n. sp., and $M$. (P.) zerchei n. sp., are described. The varieties Planeteros sibutensis v. burgeoni PIC, 1924, P. soppoensis v. bonneviei PIC, 1924 and P. bequaerti v. nigrithorax PIC, 1935, are raised to species rank. Seven taxa are synonymized: Planeteros atriventris PIC, $1922(=M$. (P.) flavus BOURGEOIS, 1905); P. soppoensis PIC, 1922 (= M. (P.) escalerai BourgeoIs, 1905); P. asperatus KLeINE, $1940(=M$. (P.) ablutus BourgeoIs, 1908); $P$. salubris KLEINE, $1940(=M$. ( $P$.) collarti PIC, 1922); $P$. bredoi KASANTSEV, 1997 (= M. (P.) burgeoni PIC, 1924, n. stat.); $P$. gigas KLEINE, $1940(=$ M. (P.) bilineatus PIC, 1931) and P. zairicus KASAnTSEv, 1997 (= M. (P.) chirindanus KleINe, 1933). Several poorly known species are illustrated.

\section{Zusammenfassung}

Neun Arten werden beschrieben: Melaneros (Planeteros) crucifer n. $\mathrm{sp}_{,}, M$. (P.) flos $\mathrm{n} . \mathrm{sp} ., M$. (P.) drymophilus n. sp., $M$. (P.) terrier n. sp., $M$. (P.) petrovi n. sp., $M$. (P.) helicofer n. sp., $M$. (P.) helicophilus n. sp., M. (P.) arndti n. sp., and $M$. (P.) zerchei n. sp. Die Varietäten Planeteros sibutensis v. burgeoni PIC, 1924, P. soppoensis v. bonneviei PIC, 1924 and $P$. bequaerti v. nigrithorax PIC, 1935, werden in den Artrang erhoben. Sieben Taxa werden synonymisiert: Planeteros atriventris PIC, $1922(=$ $M$. (P.) flavus BourgeoIs, 1905); $P$. soppoensis PIC, 1922 (=M. (P.) escalerai BouRgeoIs, 1905); $P$. asperatus KLEINE, 1940 ( $=$ M. (P.) ablutus BOURGEOIS, 1908); P. salubris KLEINE, 1940 (=M. (P.) collarti PIC, 1922); P. bredoi KASANTSEV, 1997 ( $=M$. (P.) burgeoni PIC, 1924, n. stat.); $P$. gigas KLEINE, $1940(=M$. (P.) bilineatus PIC, 1931) and P. zairicus KASANTSEV, $1997(=M$. (P.) chirindanus KLEINE, 1933). Mehrere unzulänglich bekannte Arten werden illustriert.

\section{Keywords}

Coleoptera, Lycidae, Melaneros, new species, synonymy, Tropical Africa.

\section{Introduction}

First species of the African subgenus Planeteros GORHAM, 1883 of the almost universally distributed genus Melaneros FAIRMAIRE, 1877, a senior synonym of Plateros BOURGEOIS, 1879 (BOCÁK \& BOCÁKOVÁ, 1992) were described in the eighties of the nineteenth century (GORHAM, 1883; BOURGEOIS, 1883; FAIRMAIRE, 1887). Later three more (curtus, escalerai, 
flavus) from Spanish Guinea were added, with types deposited in the National Museum of Natural Sciences in Madrid (BOURGEOIS, 1905). The consequent contributions to the knowledge of the subgenus made between 1908 and 1940 often used BOURGEOIS' taxa relying on the description, i.e. basically on the coloration of the antennae and elytra, while the type specimens were never studied. This has led to considerable confusion as the difference in coloration has appeared to be actually of little taxonomic importance, similarly coloured forms often belonging in different species. At the same time new taxa were often based on unique female specimens, whereas our research permits to regretfully assert that females in allied species are practically indistinguishable.

The first contribution resuming the study of this African subgenus after more than 50 years of negligence was based on the types deposited in the National Museum of Natural History, Paris, and the Royal Belgian Institute of Natural Sciences, Brussels (KASANTSEV, 1997). Further study of the Lycidae material, now mostly from the collections of the Royal Museum for Central Africa, Tervuren, the National Museum of Natural Sciences, Madrid, the Natural History Museum, London, and the Deutsches Entomologisches Institut, Eberswalde, including the types deposited there, allows to further contribute to the knowledge of this group adding several species unknown to science and suggesting certain synonymic and taxonomic changes.

The following abbreviations are used in the paper:

DEI Deutsches Entomologisches Institut, Eberswalde;

MNP Muséum National d'Histoire Naturelle, Paris;

NHML Natural History Museum, London;

NME Naturkundemuseum, Erfurt;

NMM Museo Nacional de Ciencias Naturales, Madrid;

RMCA Musée Royal de l'Afrique Central, Tervuren;

ICM Insect Centre, Moscow.

Descriptions and Systematic Account

Melaneros (Planeteros) curtus BouRGEOrs, 1905

Figs 1-2

Plateros (Planeteros) curtus BouRgEoIs, 1905

Material studied

female (Holotype), "Biafra" (blue rectangular), "Biafra, Cabo San Juan, VIII.1919, Escalera", "Planeteros curtus sp.nov." (BOURGEOIs' manuscript label) (NMM).

\section{Remarks}

The contradiction between the year of the take of the specimen designated as Holotype and the year of description of the taxon has the following explanation. ESCALERA, according to the information provided at the National Museum of Natural Sciences, Madrid, collected in Biafra twice - in 1901 and 1919. This material initially provided with manuscript labels only indicating "Biafra" within certain time was relabelled with more detailed printed labels, i.e. "Biafra, Cabo S.Juan, VII.1901, Escalera" for the first lot and "Biafra, Cabo San Juan, VIII.1919, Escalera" for the second. Material sent to other institutions for identification shortly after ESCALERA's first collecting trip and labelled just "Biafra" could have been returned after the 1901 lot was organised (BOURGEOIs' decease in 1910 could also have caused delay in the return of the studied lycids) and relabelled afterwards, along with the insects from the second trip. 



Figs 1-9: Front part of body and aedeagus, males: 1-2. Melaneros (Planeteros) curtus BOURGEOIs; 3-4. M. (P.) escalerai Bourgeols; 5-6. M. (P.) flavus Bourgeols; 7. M. (P.) bicoloripes PIC; 8. $M$. (P.) congoensis KLEINE; 9. M. (P.) similis KLEINE. Scale: $0.5 \mathrm{~mm}$.

Melaneros (Planeteros) escalerai BoURGEOIs, 1905

Figs 3-4

Plateros (Planeteros) escalerai BoURGEors, 1905

$=$ Planeteros soppoensis PIC, 1922, n. syn.

\section{Material studied}

female (Holotype), "Biafra" (blue rectangular), "Biafra, Cabo San Juan, VIII.1919, Escalera", "Planeteros Escalerai sp.nov." (BourGEOIS' manuscript label) (NMM). 


\section{Remarks}

Remarks on $M$. (P.) curtus above on the contradiction between the year of the take of the specimen designated as Holotype and the year of description of the taxon apply to $M$. (P.) escalerai as well.

$P$. soppoensis PIC the type of which was studied and illustrated in the previous paper (KASANTSEV, 1997) is identical with $M$. (P.) escalerai.

\section{Melaneros (Planeteros) flavus BoURGeOIS, 1905}

Figs 5-6

Plateros (Planeteros) flavus BOURGEOIS, 1905

$=$ Planeteros atriventris PIC, 1922, n. syn.

\section{Material studied}

male (Holotype), "Biafra" (blue rectangular), "Biafra, Cabo San Juan, VIII.1919, Escalera", "Plateros flavus Brg." (BouRGEOIS' manuscript label); female (Paratype), same labels (NMM).

\section{Remarks}

Remarks on $M$. (P.) curtus above on the contradiction between the year of the take of the specimen designated as Holotype and the year of description of the taxon apply to $M$. (P.) flavus as well.

$P$. atriventris PIC the type of which was studied earlier (KASANTSEV, 1997) is identical with $M(P$.$) flavus.$

\section{Melaneros (Planeteros) ablutus BOURGEOIS, 1908}

Planeteros nigricauda var. ablutus BOURGEOIS, 1908.

= Planeteros atricornis PIC, 1925: KASANTSEV,1997

= Planeteros neavei KLEINE, 1940: KASANTSEV,1997

$=$ Planeteros asperatus KLEINE, 1940, n. syn.

\section{Material studied}

male (Holotype), “Typus” (red rectangular, KLEINE's manuscript label); "Londiani, K.C. Kenya, May 1936, H.J.A.Turner”, "Planeteros asperatus Kln, R.Kleine det. 1937” (KLEINE's manuscript label) (NHML).

\section{Remarks}

$P$. asperatus the Holotype of which from the Natural History Museum, London, has been studied, is identical with $M$. (P.) ablutus illustrated in the previous paper (KASANTSEV, 1997). The aedeagus of the Holotype has been examined. The illustration provided with the description of $P$. asperatus (KLEINE, 1940) was obviously taken of a broken piece of the aedeagus of the paratype specimen.

\section{Melaneros (Planeteros) collarti PIC, 1922}

Planeteros collarti PIC, 1922

= Planeteros salubris KLEINE, 1940, n. syn.

\section{Material studied}

male (Holotype), "Holotype" (red circle); "Nyamgasani Valley, 8-9,000 ft., D.R.Buxton"; "Uganda: Ruwenzori Range, xii.1934-i.1935, B.M.E.Afr.Exp., B.M. 1935-203"; "Typus" (red rectangular); "Planeteros salubris Kln (typus), R.Kleine det. 1936" (KLEINE's manuscript labels) (NHML). 


\section{Remarks}

$P$. salubris the Holotype of which has been studied is identical with $M$. (P.) collarti that was illustrated in the previous paper (KASANTSEV, 1997).

\section{Melaneros (Planeteros) bicoloripes PIC, 1923}

Fig. 7

Planeteros bicoloripes PIC, 1923

\section{Material studied}

female (Lectotype, hereby designated to clarify the application of the name to a taxon), "Sierra Leone", "Planeteros bicoloripes n.sp." (PIC's manuscript labels) (MNP); male, "Haute Cote d'Ivoire, bassins de la Haut-Nuga et du Haut-Cavally, Danané et environs, A.Chevalier, 1910", "Avril"; female, "Cote d'Ivoire, Haut-Sassandra, Pays Oydla, entre Zoahle et Sanrou (F.Fleury), A.Chevalier, 1910", "Mai" (MNP and ICM).

\section{Melaneros (Planeteros) congoensis KLEINE, 1930}

Fig. 8

\section{Material studied}

male (Lectotype, hereby designated to clarify the application of the name to a taxon), "Paratype", "Musée du Congo, Albertville, xii.1918, R.Mayné", "R. det. 1633 G" (RMCA).

\section{Remarks}

In the collection of the Royal Museum for Central Africa where all types of this taxon are deposited (KLEINE, 1930), two type specimens of $M$. (P.) congoensis have been found, labelled as "Holotype" and "Paratype". The two specimens belong however in two different species, the paratype being the specimen illustrated (KLEINE, 1930). The original description does not indicate that KLEINE designated any of the 5 mentioned syntypes as Holotype. Therefore in compliance with the International Code of Zoological Nomenclature the illustrated syntype is designated as the Lectotype of the taxon. The specimen marked as "Holotype" is $M$. (P.) burgeoni PIC, 1924, n. stat.

$M$. (P.) congoensis differs from $M$. (P.) chirindanus by the larger eyes, rounded apically scutellum, wider pronotal infuscation and the shape of the aedeagus with definitely narrower apical half and bent apex (Fig. 8).

\section{Melaneros (Planeteros) bilineatus PrC, 1931}

$=$ Planeteros gigas KLEINE, 1940, n. syn.

\section{Material studied}

female (Holotype), "Type, P. gigas" (red), "Coll. Mus. Congo, Mongbwalu, 20.V.1939, Mme A.Lepersonne", "Type", "R.det. G 4040", "Planeteros gigas Kln, R.Kleine det. 1940" (KLEINE's manuscript label) (RMCA).

\section{Remarks}

$P$. gigas is identical with $M$. (P.) bilineatus the type of which was studied and illustrated in the previous paper (KASANTSEV, 1997). The absence or presence of apical elytral infuscation lies within the limits of infraspecific variability. 

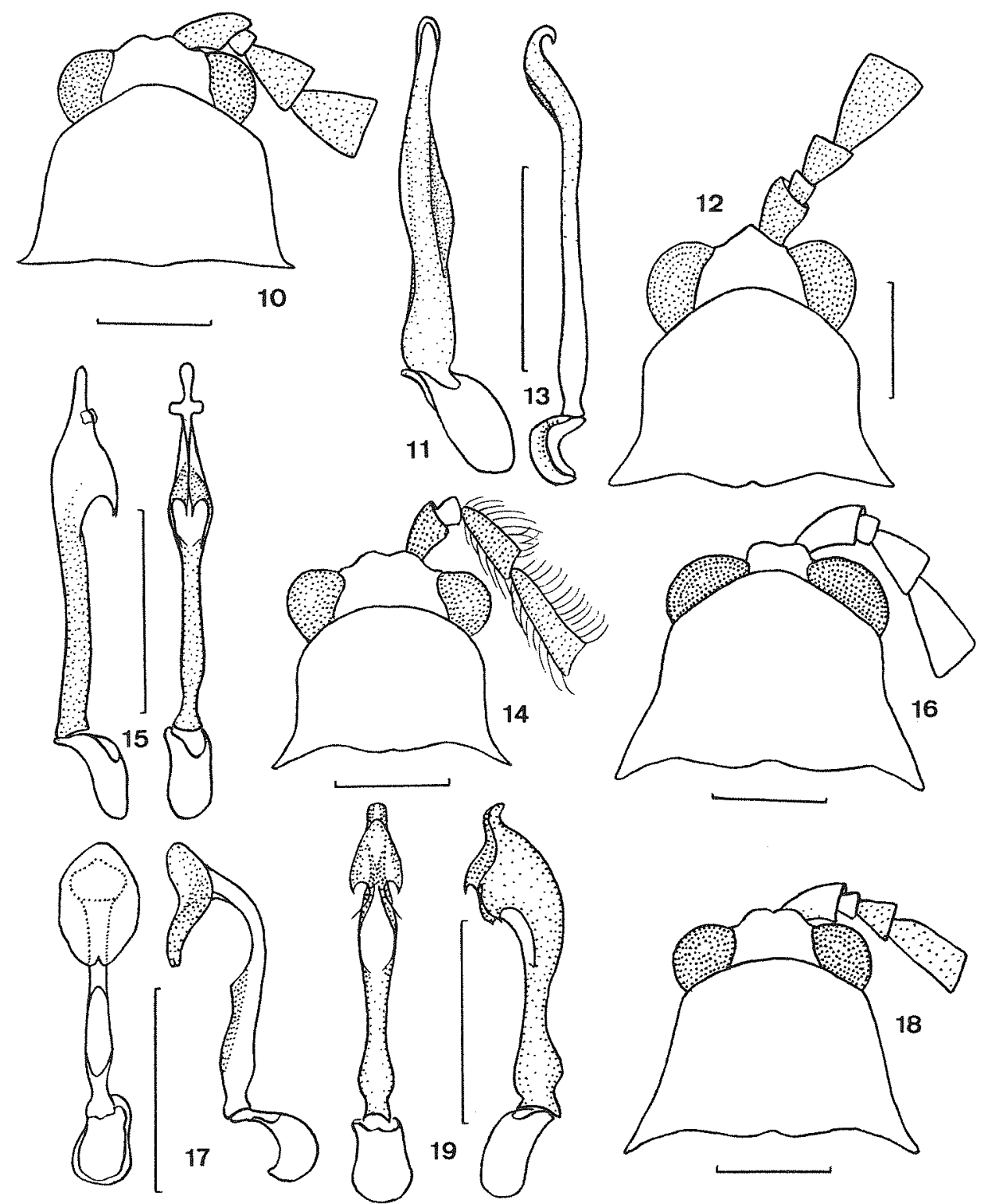

Figs 10-19: Front part of body and aedeagus, males: 10-11. Melaneros (Planeteros) nigrithorax PIC; 1213. $M$. (P.) bonneviei PIC; 14-15. $M$. (P.) crucifer n. sp.; 16-17. $M$. (P.) flos n. sp.; 18-19. M. (P.) drymophilus n. sp. Scale: $0.5 \mathrm{~mm}$.

\section{Melaneros (Planeteros) chirindanus KLEINE, 1933}

\section{= Melaneros (Planeteros) zairicus KASANTSEV, 1997, n. syn.}

\section{Material studied}

male (Holotype), "Type" (red circle); "Chirinda, Gaza Ld.Dec.1901, G.A.K.Marshall, 1908212"; "Planeteros chirindanus Kln, [male] Typus, R.Kleine det." (KLEINE's manuscript label) (NHML). 


\section{Remarks}

The study the Holotype of $M$. (P.) chirindanus has shown that $M$. (P.) zairicus is identical with it. The absence or presence of pronotal discal infuscation lies within the limits of infraspecific variability.

\section{Melaneros (Planeteros) similis KLEINE, 1933}

Fig. 9

Planeteros similis KLEINE, 1933

= Planeteros simillimus KLEINE, 1930

\section{Material studied}

male (Holotype), "Holotype", "Musée du Congo, Albertville, XII.1918, R.Mayné", "R.Dét. i 1633", "Planeteros simillimus Kln., R.Kleine det, 1929” (KLEINE's manuscript label), "nom modifié en similis Kleine" (RMCA).

\section{Remarks}

$M$. (P.) similis is close to $M$. (P.) burgeoni, distinguishable in addition to the shape of the aedeagus (Fig. 9 ) by the definitely smaller eyes, almost parallel sided antennae the $3 \mathrm{rd}$ segment of which is considerably (1.5 times) shorter than the 4 th.

Melaneros (Planeteros) nigrithorax PIC, 1935, n. stat. Figs 10-11

Planeteros bequaerti var. nigrithorax PIC, 1935

\section{Material studied}

female (Lectotype, hereby designated to clarify the application of the name to a taxon), "Type, var. nigrithorax", "Musée du Congo, Kivu: Luvungi, XII.1932, L.Burgeon”, "R.Dét. X 3002 ", "Planeteros bequaerti v. nigrithorax mihi" (PIC's manuscript label) (RMCA).

\section{Remarks}

Though described as a variation of bequaerti $M$. (P.) nigrithorax is definitely different from the nominative form by the coloration details, the structure of the antennae and the aedeagus (Figs. 10-11).

Melaneros (Planeteros) burgeoni PrC, 1924, n. stat.

Planeteros sibutensis var. burgeoni PIC, 1924

$=$ Melaneros (Planeteros) bredoi KASANTSEV, 1997, n. syn.

\section{Material studied}

male (Lectotype, hereby designated to clarify the application of the name to a taxon), "Holotype", "Musée du Congo, K 185, Maleba, i.1914, L.Burgeon", "R.Dét. N 1104", "Planeteros sibuti v. nov. Burgeoni" (PIC's manuscript label) (RMCA).

\section{Remarks}

$M$. (P.) burgeoni the Lectotype of which from the Royal Museum of Central Africa, Tervuren, has been studied, appears to be different from $M$. (P.) sibutensis and identical with $M$. (P.) bredo $i$ described in the previous paper (KASANTSEV, 1997). 
Melaneros (Planeteros) bonneviei PIC, 1924, n. stat.

Figs 12-13

Planeteros soppoensis var. bonneviei $\mathrm{PIC}, 1924$

\section{Material studied}

male (Lectotype, hereby designated to clarify the application of the name to a taxon), "Holotype", "Musée du Congo, Lesse, Lt. Bonnevie", "R.Dét. O 1104", "Planeteros soppoensis v. nov. Bonneviei" (PIC's manuscript label) (RMCA).

\section{Remarks}

$M$. (P.) bonneviei approaches $M$. (P.) bicoloripes in the type of the aedeagus, but is readily distinguishable by the absence of a tooth in the apical cavity and the bent apex (Fig. 13).

\section{Melaneros (Planeteros) crucifer $\mathrm{n.sp}$.}

Figs 14-15

\section{Description}

Dark brown; second and apical half of eleventh antennal joint, pronotal margins, elytra except apical sixth and front and middle trochanters and femurs (basally) testaceus.

Male. Head with round impression behind antennal prominence. Eyes relatively small (interocular distance twice as long as radius). Maxillary palpi slender, with ultimate joint elongate, almost parallel sided, flattened anteriorly, 1.5 times longer than $3 \mathrm{rd}$. Antennae flattened, moderately spinose apically from joint 4 , reaching $5 / 6$ of elytra, with 3rd joint conspicuously longer than 2 nd and about 1.5 times shorter than 4 th and following joints (Fig. 14); joints 3-11 with long hairs.

Pronotum transverse, 1.3 times wider than long, slightly diverging posteriorly, with almost straight sides, rounded anterior margin, blunt anterior and acute produced laterally and posteriorly hind angles (Fig. 14).

Scutellum square, parallel sided, straight at apex.

Elytra long, 3.9 times as long as wide humerally, slightly widening posteriorly, with 4 primary costae, humeral definitely more elevated except in apical $1 / 6$, interstices with double rows of rounded cells; pubescence uniform, dense and relatively short, half erect, testaceus in testaceus part and brownish in darkened portion.

Aedeagus with cross in ventral view (Fig. 15).

Length: $5.0 \mathrm{~mm}$. Width (humerally): $1.2 \mathrm{~mm}$.

Female. Similar to male, but antennae shorter, without long hairs, three apical joints testaceus, eyes slightly smaller and body more robust.

\section{Type material}

Holotype male: "Congo belge: Kivu, Rutshuru (riv. Rodahira), 1285 m, 2.vii.1935, G.F. de Witte: 1675", "Coll. Mus. Congo", "R.Dét. L. 4825", "Planeteros flavoapicalis Kln. R.Kleine det." (KLEINE's maniscript label) (RMCA); Paratypes: female, "Congo Belge: P.N.A., 1318.II.1953, P. Vanschuytbroeck \& V. Hendrickx 2149-51", "Secteur Nord, Mutsora, 11001150 m, Riv. N'Gokoi, affl. Talya" (RMCA); male, "Congo Belge: P.N.A., 26-28. VIII.1953, P. Vanschuytbroeck \& V. Hendrickx 4999-5005", "Secteur Tshiaberimu, Riv. Mbulikerere, affl. dr. Talia N, 2720 m" (ICM); 2 females, "Congo Belge: P.N.A., 7-15.VII.1955, P. Vanschuytbroeck 13274-309", "Mont Hoyo, $1280 \mathrm{~m}$, sur plantes basses" (RMCA and ICM); "Afrique occ., Guinée, Forêt Tabouna, 24.XI.1982, S.Murzin leg." (ICM). 


\section{Diagnosis}

In the structure of the aedeagus $M$. (P.) crucifer n. sp. is similar to $M$. (P.) similis, but can be distinguished in having a small cross in the apical portion and other details (Fig. 15). At the same time long hairs of the antennal pubescence in combination with almost parallel sided spinose apically joints are not known in other Melaneros species from Africa.

In the paratype from Guinea all the elytra are uniformly testaceus.

\section{Melaneros (Planeteros) flos n. sp.}

Figs 16-17

\section{Description}

Dark brown; first partially, second and apical antennal joints, pronotum, scutellum and elytra except apical touch testaceus.

Male. Head with round impression behind antennal prominence. Eyes relatively large (interocular distance about as long as radius). Maxillary palpi slender, with ultimate joint elongate, slightly widened and flattened apically, about 1.5 times longer than $3 \mathrm{rd}$. Antennal joints flattened, almost parallel sided, reaching $5 / 6$ of elytra, with 3 rd joint conspicuously longer than 2 nd and about 1.3 times shorter than 4 th and following joints (Fig. 16); joints 3-11 with short bristling pubescence.

Pronotum transverse, 1.4 times wider than long, with almost straight sides, triangular anterior margin, conspicuous anterior and acute produced laterally and posteriorly hind angles (Fig. 16). Scutellum square, parallel sided, gently emarginate at apex.

Elytra long, 3.7 times as long as wide humerally, slightly widening posteriorly, with 4 primary costae, interstices with double rows of rounded cells; pubescence dense and relatively short, half erect, spread throughout, testaceus in testaceus part and brownish in darkened portion.

Aedeagus with flower-like apical structure (Fig. 17).

Length: 4.0-5.6 mm. Width (humerally): $1.0-1.35 \mathrm{~mm}$.

Female. Unknown.

\section{Type material}

Holotype male: "Musée du Congo, Haut Uelé: Moto, 1920, L.Burgeon" (RMCA); Paratypes: male, "Musée du Congo, Kai Bumba, 10.X.1920, Dr. H.Schouteden", "R. dét. 1633, B", "Plateros curtus Bourg., R.Kleine det. 1929" (KLEINE's manuscript label) (RMCA); male, "Congo Belge, Libutu, Kituri, 6.IX.1929, A.Collart" (ICM); male, "Mico'meseng, Guinea Española, Dr. L.Bágena" (NMM).

\section{Diagnosis}

Belonging in the same group as $M$. (P.) crucifer, $M$. (P.) flos n. $\mathrm{sp}$. is readily distinguishable by the antennae and the dilated and widened flower-like apex of the aedeagus (Fig. 17).

The apical infuscation may be absent, as in the paratypes from Guinea and Libutu where all the elytra are uniformly testaceus. In the former unlike in the other specimens of the type series two apical antennal segments are testaceus. The femora and tarsi can vary from uniformly dark brown to uniformly testaceus.

\section{Melaneros (Planeteros) drymophilus n. sp.}

Figs 18-19

\section{Description}

Testaceus; 3rd to 9th antennal joints, metasternum, abdomen except apical segment, elytra apically, tibiae and tarsi dark brown. 
Male. Head with shallow impression behind antennal prominence. Eyes relatively large (interocular distance about 1.5 times as long as radius). Maxillary palpi slender and short, with ultimate joint short, slightly flattened and narrowed anteriorly, about 1.5 times longer than 3 rd. Antennae flattened, reaching about $2 / 3$ of elytra, with 3 rd joint conspicuously longer than 2 nd and twice as short as 4 th and following joints (Fig. 18); joints 3-11 with short erect dense pubescence.

Pronotum transverse, 1.7 times wider than long, diverging posteriorly, with rounded anterior margin, blunt anterior and acute produced laterally and posteriorly hind angles (Fig. 18).

Scutellum transverse, parallel sided, slightly emarginate at apex.

Elytra relatively long, 3 times as long as wide humerally, slightly widening posteriorly, with 4 primary costae, interstices with double rows of rather irregular cells; pubescence dense and relatively short, half erect, spread throughout, testaceus in testaceus part and brownish in darkened portion.

Aedeagus with two pairs of teeth apically (Fig. 19).

Length: $4.7 \mathrm{~mm}$. Width (humerally): $1.2 \mathrm{~mm}$.

Female. Unknown.

\section{Type material}

Holotype male: "Afrique occ., Guinée, Forêt Tabouna, 6.VI.1984, S.Murzin leg." (ICM).

Diagnosis

Habitually $M$. (P.) drymophilus n. sp. is similar to $M$. (P.) menieri KasANTSEV, 1997, approaching $M$. (P.) terrier n. sp. in the shape of the aedeagus, easily distinguishable from both by the details of the latter (Fig. 19).

\section{Melaneros (Planeteros) terrier n. sp.}

Figs 20-21

\section{Description}

Dark brown; 2nd and apically 11 th antennal joints, palpi except terminal joints, pronotal margins, elytra except apical third and trochanters and femurs (basally) testaceus.

Male. Head with shallow wide impression behind antennal prominence. Eyes relatively large (interocular distance about 1.5 times as long as radius). Maxillary palpi slender and short, with ultimate joint slightly elongate, parallel sided, over twice as long as $3 \mathrm{rd}$. Antennae flattened, narrowed apically, reaching about $2 / 3$ of elytra, with 3 rd joint conspicuously longer than 2 nd and 1.75 times as short as 4th and following joints (Fig. 20); joints 3-11 with short erect dense pubescence.

Pronotum transverse, 1.4 times wider than long, with almost parallel sides, rounded anterior margin, blunt anterior and acute produced laterally hind angles (Fig. 20).

Scutellum small, square, slightly emarginate at apex.

Elytra long, 3.1 times as long as wide humerally, slightly widening posteriorly, with 4 primary costae, interstices with double rows of rather irregular cells; pubescence dense and relatively short, half erect, spread throughout, testaceus in testaceus part and brownish in darkened portion.

Aedeagus with pair of long lower teeth apically (Fig. 21).

Length: 4.6-5.2 mm. Width (humerally): $1.2-1.4 \mathrm{~mm}$.

Female. Unknown.

\section{Type material}

Holotype male: "Afrique occ., Guinée, Tabouna Vallée, 15.V.1982, S.Murzin leg." (ICM); "Afrique occ., Guinée, Lavi, 15.V.1984, S.Murzin leg." (ICM). 

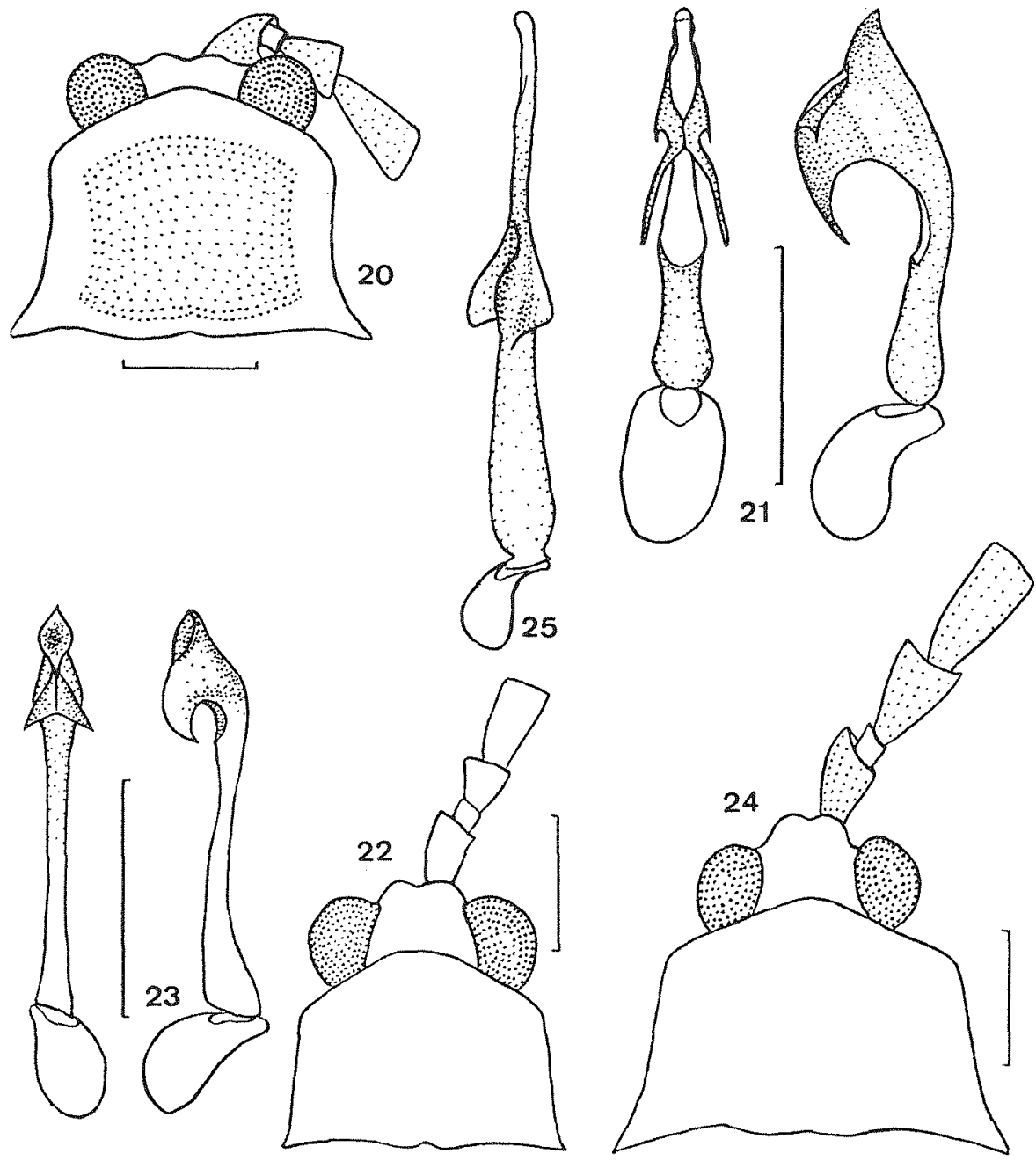

Figs 20-25: Front part of body and aedeagus, males: 20-21. Melaneros (Planeteros) terrier $\mathrm{n}$. sp.; 22-23. M. (P.) petrovi n. sp.; 24-25. M. (P.) helicofer n. sp. Scale: $0.5 \mathrm{~mm}$.

\section{Diagnosis}

In many aspects $M$. (P.) terrier n. sp. is similar to M. (P.) drymophilus n. sp., but is readily distinguishable by the black coloration of the head, pronotal disk, elytral apical third and some of the other parts of the body, the aedeagus having definitely longer and differently shaped apical teeth (Fig. 21).

\section{Melaneros (Planeteros) petrovi n. sp.}

Figs 22-23

\section{Description}

Dark brown; pronotum, elytra and femurs and tibiae (basally) testaceus.

Male. Head shining, with wide shallow impression behind antennal prominence. Eyes relatively large (interocular distance about as long as radius). Maxillary palpi slender, with ultimate 
joint elongate, strongly narrowed anteriorly, 1.5 times longer than $3 \mathrm{rd}$. Antennae flattened, narrowed apically, reaching about half of elytra, with 3 rd joint conspicuously longer than 2 nd and 1.75 times as short as 4 th and following joints (Fig. 22); joints 3-11 with dense short erect pubescence.

Pronotum transverse, 1.3 times wider than long, with almost parallel sides, produced anterior margin, blunt anterior and acute hind angles (Fig. 22).

Scutellum small, square, straight at apex.

Elytra long, 7.2/2.1 times as long as wide humerally, slightly widening posteriorly, with 4 primary costae, interstices with double rows of irregular cells; pubescence dense and relatively short, half erect, spread throughout, testaceus in testaceus part and brownish in darkened portion.

Aedeagus with pair of crooked apical teeth (Fig. 23).

Length: $4.6 \mathrm{~mm}$. Width (humerally): $1.05 \mathrm{~mm}$.

Female. Unknown.

\section{Type material}

Holotype male: "Equat. Guinea, env. Evinayong, 1974, Petrov leg." (ICM).

\section{Diagnosis}

$M$. (P.) petrovi n. sp. somewhat resembles $M$. (P.) drymophilus n. sp., distinguishable by the larger eyes and the shape of the aedeagus (Fig. 23).

\section{Melaneros (Planeteros) helicofer $\mathrm{n} . \mathrm{sp}$.}

Figs 24-25

\section{Description}

Dark brown; second antennal joint, pronotum, elytra except apical seventh (to eighth) and front and middle trochanters and femurs (basally) testaceus.

Male. Head with shallow broad impression behind antennal prominence. Eyes relatively small (interocular distance 1.5 times as long as radius). Maxillary palpi slender, with ultimate joint elongate, almost parallel sided, flattened anteriorly, more than twice as long as $3 \mathrm{rd}$. Antennae flattened, moderately spinose apically from joint 4 , reaching $6 / 7$ of elytra, with 3 rd joint 3 times longer than 2 nd and about 1.2 times shorter than 4 th and following joints (Fig. 24); joints 3-11 with relatively long erect vestiture.

Pronotum transverse, 1.5 times wider than long, slightly diverging posteriorly, with triangular anterior margin, blunt anterior and acute produced laterally and posteriorly hind angles (Fig. 24). Scutellum square, parallel sided, rounded at apex.

Elytra moderately long, 3 times as long as wide humerally, slightly widening posteriorly, with 4 equally developed primary costae, little differing from secondary ones, interstices with rows of even elongate cells; pubescence uniform, relatively dense and long, half erect, testaceus in testaceus part and brownish in darkened portion.

Aedeagus screwed medially (Fig. 25).

Length: 5.2-7.2 mm. Width (humerally): $1.4-1.6 \mathrm{~mm}$.

Female. Similar to male, but antennae shorter, not dentate, with shorter pubescence, three apical joints testaceus, eyes slightly smaller and body more robust.

\section{Type material}

Holotype male: "Musée du Congo, Equateur: Boende, 1927, R.P.Hulstaert", "R.Dét. 1698 P" (RMCA); Paratypes: male, "Musée du Congo, Haut-Uelé: Watsa, 1922, L.Burgeon", "R.Dét. 1633 R"; male, "Mus. Roy. Afr. Centr., Kasongo, IX.1959, P.L.G.Benoit"; male and 2 
females, "Congo Belge: P.N.A., 13-18.II.1953, P. Vanschuytbroeck \& V. Hendrickx 214951", "Secteur Nord, Mutsora, 1100-1150 m, Riv. N'Gokoi, affl. Talya" (RMCA); male, "Congo Belge: P.N.A., 7-15.VII.1955, P. Vanschuytbroeck 13274-309", "Mont Hoyo, 1280 m, sur plantes basses" (RMCA and ICM).

\section{Diagnosis}

$M$. (P.) helicofer $\mathrm{n}$. sp. is to be put near M. (P.) bredoi, also with twisted median lobe of the aedeagus, but is readily distinguishable by the coloration of the body and by the longer screwlike median projections (Fig. 2).

The Holotype of $M$. (P.) helicofer stood in the RMCA collection as Planeteros escalerai determined by KLEINE.


Figs 26-29: Front part of body and aedeagus, males: 26-27. Melaneros (Planeteros) helicophilus n. sp.; 28-29. $M$. (P.) arndti n. sp. Scale: $0.5 \mathrm{~mm}$.

Melaneros (Planeteros) helicophilus m. sp.

Figs $26-27$

\section{Description}

Dark brown; second antennal joint, pronotum, scutellum, elytra except apical seventh and trochanters, femurs (basally) and tarsi testaceus.

Male. Head with broad shallow impression behind antennal prominence. Eyes relatively large (interocular distance about as long as radius). Maxillary palpi slender, with ultimate joint slightly elongate, flattened anteriorly, 1.5 times longer than 3 rd. Antennae flattened, dentate, reaching $5 / 6$ of elytra, with 3 rd joint 4 times longer than 2 nd and about 1.2 times shorter than 4 th and following joints (Fig. 26); joints 3-11 with relatively long erect vestiture. 
Pronotum transverse, 1.5 times wider than long, diverging posteriorly, with conspicuously concave anterior margin, blunt anterior and acute produced laterally and posteriorly hind angles (Fig. 26).

Scutellum square, parallel sided, slightly emarginate at apex.

Elytra long, 3.2 times as long as wide humerally, slightly widening posteriorly, with 4 primary costae, interstices with double rows of elongate cells, somewhat irregular in apical fourth; pubescence uniform, dense and relatively long, half erect, testaceus in testaceus part and brownish in darkened portion.

Aedeagus with twisted median piece (Fig. 27).

Length: $5.0 \mathrm{~mm}$. Width (humerally): $1.2 \mathrm{~mm}$.

Female. Similar to male, but antennae shorter, without long hairs, three apical joints testaceus, eyes slightly smaller and body more robust.

\section{Type material}

Holotype male: "Musée du Congo, Equateur: Flandria, 8.XII.1930, R.P.Hulstaert 54", "Planeteros Escalerai Bourg. var.” (PIC's manuscript label) (RMCA)

\section{Diagnosis}

$M$. (P.) helicophilus n. sp. is similar to $M$. (P.) bredoi and $M$. (P.) helicofer, distinguishable by the coloration and the shape of the aedeagus (Fig. 27).

\section{Melaneros (Planeteros) arndti n. sp.}

Figs 28-29

\section{Description}

Black; second antennal joint and $5 / 9$ of elytra anteriorly testaceus.

Male. Head with feeble round impression behind antennal prominence. Eyes relatively small (interocular distance 2.2 times longer than radius). Labrum transverse, slightly rounded anteriorly. Maxillary palpi slender, with ultimate joint parallel sided, flattened anteriorly, only slightly longer than wide. Antennae flattened, slightly dentate from joint 3 , half as long as the body, with 3 rd joint conspicuously longer than 2 nd and only slightly shorter than 4 th and following joints (Fig. 28); pubescence moderately long and erect.

Pronotum transverse, 1.45 times wider than long, slightly diverging posteriorly, with almost straight sides, blunt anterior and acute slightly produced laterally hind angles (Fig. 28).

Scutellum square, parallel sided, with feeble wide emargination at apex.

Elytra relatively long, 3.1 times as long as wide humerally, widening posteriorly, with 4 distinct primary costae equally elevated throughout, interstices with double rows of well defined square cells; pubescence long, half erect, spread along costae, testaceus in testaceus part and black in black part.

Aedeagus with narrow process covering median cavity (Fig. 29).

Length: $5.7 \mathrm{~mm}$. Width (humerally): $1.5 \mathrm{~mm}$.

Female. Unknown.

\section{Type material}

Holotype male: Burundi, $10 \mathrm{~km}$ W Bujumbura, 9.ii.(19)92, fc. Arndt (NME).

\section{Diagnosis}

M. (P.) arndti n. sp. is similar to $M$. (P.) seminigrans KASANTSEV, 1997, but is readily distinguishable by the presence of a narrow process covering the median cavity and other details of the aedeagus (Fig. 29). 


\section{Melaneros (Planeteros) zerchei n. sp.}

\section{Description}

Dark brown; $9^{\text {th }}$ to $11^{\text {th }}$ antennal joints, scutellum and elytra except apical eighth testaceus. Male. Head with shallow round impression behind antennal prominence. Eyes relatively large (interocular distance 1.2 times longer than radius). Maxillary palpi slender. Antennae flattened, reaching over elytral two thirds, joints parallel sided, with 3rd twice as long as 2 nd and 1.3 times shorter than 4 th and following joints; pubescence dense and erect.

Pronotum almost square, only 1.1 times wider than long, slightly diverging posteriorly, with slightly concave sides, blunt anterior and acute slightly produced laterally hind angles.

Scutellum transverse, parallel sided, with feeble wide emargination at apex.

Elytra relatively long, 3.5 times as long as wide humerally, widening posteriorly, with 4 primary costae equally elevated throughout, interstices with double rows of well defined square cells; pubescence uniform, relatively long, half erect, testaceus in testaceus part and black in black part.

Aedeagus long and narrow, with hooked apical portion.

Length: $5.0 \mathrm{~mm}$. Width (humerally): $1.2 \mathrm{~mm}$.

Female. Unknown.

\section{Type material}

Holotype male: "Kamerun, Conradt", "Koll. Kraatz", "Planeteros Escalerai Bourg., R.Kleine det. 1934" (KLEINE's manuscript label) (DEI).

\section{Diagnosis}

$M$. (P.) zerchei n. sp. may be placed near $M$. (P.) guineensis KASANTSEV, 1997, but is distinguishable by the coloration and the hooked apical portion of the long and narrow aedeagus.

\section{Acknowledgements}

It is my pleasant duty to express my sincere gratitude to Dr. E. DE CONINCK and Dr. M. DE MEYER (Musée Royal de l'Afrique Central, Tervuren) Dr. M. ZarazAGa (Museo Nacional de Ciencias Naturales, Madrid), Ms. J. BEARD (Natural History Museum, London), Dr. L. ZERCHE (Deutsches Entomologisches Institut, Eberswalde) and Dr. E. ARNDT (Naturkundemuseum, Erfurt) through whose courtesy I was able to work with the Lycidae collections of the mentioned institutions and study the necessary types.

\section{References}

BoCÁK, L. \& BOCÁKOVÁ, M. 1992: Notes on some genera of the family Lycidae (Insecta: Coleoptera). Entom. Basil. 15: 255-260.

BoURGEOIS, J. 1883: Lycides nouveaux ou peu connus du Musée civique de Gênes. - Ann. Mus. Civ. St.

Nat. Genoa, 18: 621-648.

BourgeoIs, J. 1905: Malacodermes de la Guinée Espagnole. - Mem. Soc. Espan. Hist. nat, 1: 189-196. BouRGEOIS, J. 1908: Collections recueillies par M. Ch. Allouad dans l'Afrique Orientale (1903-1904). -

Bull. Mus. Hist. Nat., 14: 270-275.

FAIRMAIRE, L. 1877: Descriptions de Coléoptères nouveaux. - Petit Nouv. Ent., 2: 173.

FAIRMAIRE, L. 1887: Coléoptères des Voyages de M. G. Revoil chez les Somalis et dans 1'Interieur du Zanquebar. - Ann. Soc. entom. France, 6 (6): 334-341.

GoRHAM, H. S. 1883: Descriptions of Malacodermata in the Civic Museum of Natural History at Genoa.

- Ann. Mus. Civ. St. Nat. Genoa, 18: 591 -597. 
KASANTSEV, S. 1997: Sur le sous-genre Planeteros (Coleoptera, Lycidae). - Rev. fr. d'Entom. (N.S.), 19 (1-2): 7-17.

KLEINE, R. 1930: Fier neue Plateros-Arten aus dem belgischen Congo nebst faunistischen Bemerkungen. - Rev. Zool. Bot. Afr., 19 (2): 167-171.

KLEINE, R. 1933: Neue Lyciden und Bemerkungen zum Cat. Col. Junk-Schenkling Lycidae. - Stett. Entom. Ztschr., 94: 1-20.

KLEINE, R. 1940: Neue Brenthiden und Lyciden aus dem Congo-Museum. - Rev. Zool. Bot. Afr., 33 (3): 245-255.

KLEINE, R. 1940: Bestimmungsschlüssel der afrikanischen Plateros-(Planeteros) Arten. - Mitt. Münch. Entom. Ges., 30: 887-896.

PIC, M. 1923: Nouveaux Coléoptères exotiques. - Ann. Soc. Linn. Lyon (N.S.), 69: 73-74.

PIC, M. 1924: Coléoptères Malacodermes du Congo Belge. - Rev. Zool. Bot. Afr., 12: 437-443.

PIC, M. 1931: Malacodermes exotiques. - L'Echange, 446: 105-106.

PIC, M. 1935: Nouveaux Lycides africains (Malacodermata). - Rev. Zool. Bot. Afr., 26 (4): 445-447.

\author{
Author's address: \\ SERGEI KASANTSEV \\ 13-326 Donetskaya \\ 109651 Moscow \\ Russia
}

\title{
Besprechungen
}

AMIET, F.: Apidae 2 (Colletes, Dufourea, Hylaeus, Nomia, Nomioides, Rhophitoides, Rophites, Sphecodes, Systropha). - Unter Mitarbeit von A. MÜLLER \& R. NEUMEYER.- Neuchâtel: Schweizer. Ent. Gesell., 1999. - (Fauna Helvetica; 4). - 219 S., 307 Abb., 98 Verbreitungskarten. - ISSN 1422-6367. CHF 45,00

Dies ist die Fortsetzung des Bienen-Bandes 1 der Insecta Helvetica (1996), der neben dem allgemeinen Teil einen Gattungsschlüssel und die Bearbeitung der Hummeln enthielt. Die Schweizerische Entomologische Gesellschaft und das Centre suisse de cartographie de la faune wollen ihre Reihen künftig gemeinsam unter dem Serientitel Fauna Helvetica herausgeben, was man am veränderten Format - leider - sofort bemerkt. Im übrigen aber ist das bewährte Konzept beibehalten worden. Die Gattungen, in den Diagnosen auch die Arten, werden in alphabetischer Reihenfolge abgehandelt. Einer kurzen Einführung der Gattung folgt ein reich illustrierter Bestimmungsschlüssel und eine systematische Übersicht, dieses auch in französischer Sprache. Der Autor hat die meisten Schlüssel selbst entworfen, sie aber in jedem Fall kritisch geprüft und nach seinem Verständnis neu gestaltet, einschließlich der vielen Originalzeichnungen. Dies macht das Buch außerordentlich brauchbar. Weiteren besonderen Wert gewinnt es aus der kritischen Sichtung des in Schweizer Museums- und Privatsammlungen vorhandenen Belegmaterials, das für die Verbreitungskarten mit herangezogen worden ist. An der Prüfung der Daten und der Schlüssel haben die beiden Koautoren mitgewirkt.

Insgesamt ist der solide Grund der Schweizer Bienenfaunistik weiter verstärkt worden. Man erinnere sich des „Verzeichnis der Bienen der Schweiz“" von 1991, Nachtrag 1992, und der „Roten Liste der gefährdeten Bienen der Schweiz", 1994, alle vom gleichen Autor. Hier nun wird eine sehr persönliche, praxisgeprüfte, von zahlreichen Kollegen gern unterstützte Bearbeitung vorgelegt, die die Zahl der Entomologen mehren dürfte, die sich künftig die Bienen auch im Felde näher ansehen werden. Bleibt zu hoffen, daß das Werk zügig fortgesetzt und in gleicher Weise recht bald vollendet werden kann. 